\title{
Radial Permeability of the Hybrid Pine (Pinus elliottii x Pinus caribaea) in Australia
}

\author{
William Leggate, ${ }^{\mathrm{a}, *}$ Adam Redman, ${ }^{\mathrm{b}}$ Jeff Wood, ${ }^{\mathrm{c}}$ Henri Bailleres, ${ }^{\mathrm{b}}$ and David J. Lee ${ }^{\mathrm{d}}$ \\ The radial permeability (gas and liquid) of the hybrid pine (Pinus elliottii \\ var. elliottii $[\mathrm{PEE}] \times$ Pinus caribaea var. hondurensis $[\mathrm{PCH}])$ was \\ investigated for wood samples collected from 30 trees that were 19 years \\ of age and represented various genotypes and stocking rates. The PEE $\times$ \\ $\mathrm{PCH}$ hybrid is now a very important resource for the Australian forestry \\ industry, producing logs used to manufacture a diverse array of wood \\ products. The permeability of wood influences many important wood \\ properties and industrial processes. For all data combined from all radial \\ sampling positions, there was no significant effect of genotype and \\ stocking rate on radial permeability. Both gas and liquid permeability \\ increased from pith to bark positions within the tree. Conversely, resin \\ content decreased from pith to bark positions. Gas and liquid permeability \\ were significantly positively correlated, and a highly significant negative \\ relationship was also found between permeability (gas and liquid) and \\ resin content.
}

Keywords: Wood permeability; Resin content; Hybrid pine; Pinus elliottii var. elliottii; Pinus caribaea var. hondurensis, Southern pine

Contact information: a: Research School of Physics and Engineering, The Australian National University, Canberra, ACT 0200, Australia; b: Queensland Department of Agriculture and Fisheries, Horticulture and Forestry Science, Salisbury Research Facility, 50 Evans Road, Salisbury, Queensland, 4107 Australia; c: Fenner School of Environment and Society, The Australian National University, Canberra, ACT 0200, Australia; d: Forest Industries Research Centre, University of the Sunshine Coast, Maroochydore, Queensland, 4558, Australia; *Corresponding author: william.leggate@anu.edu.au

\section{INTRODUCTION}

Australian subtropical plantation exotic pine resources include slash pine (Pinus elliotii var. elliotii) [PEE], Caribbean pine (Pinus caribaea var. hondurensis) [PCH], and locally developed hybrids known as PEE $\times$ PCH (Hybrid pine F1 and F2), as well as smaller areas of loblolly pine (Pinus taeda) (Lee 2015). The hybrid pine PEE $\times$ PCH now dominates exotic softwood plantations in Queensland with around 94,100 hectares planted and an estimated annual log production volume soon to exceed 1 million $\mathrm{m}^{3} /$ year (Personal Communication, HQ Plantations 2018). The subtropical plantation exotic pine resources comprise approximately $15 \%$ of the Australian softwood plantation estate (approximately 156,600 hectares), supporting a diverse processing sector that includes sawn timber, engineered wood products, panels, landscaping, and lower grade end uses (Lee 2015).

Permeability is the property of a material that indicates how freely fluids and gases flow through them in response to a pressure gradient (Milota et al. 1994). In the case of wood, liquid and gas permeability is determined by measuring the rate of flow of fluid and gas through a wood specimen of known length and cross-sectional area while a known pressure difference is applied across it (Booker 1977). Gas and liquid permeability are usually closely correlated (Comstock and Côté 1968; Taghiyari 2012), but due to higher 
viscosity, molecular size, and liquid-wood interactions, liquid permeability is usually much lower. For example, water permeability in wood has been shown to be around 50 times less compared to air permeability at the same temperature (Siau 1984).

The permeability of wood to liquids and gases influences many important processes, including treatment with preservatives, wood modification systems, drying, chemical pulping, gluing, and finishing (Fogg 1968; Tesoro 1973; Hansmann et al. 2002; Zimmer et al. 2014). Generally, less permeable wood types are more difficult to treat and dry (Milota et al. 1994). Wood permeability can also influence its durability (Nicholas et al. 2005; Sandberg and Salin 2012).

Fluid migration in wood uses the vascular system developed by trees for physiological requirements (Redman 2017). Therefore, wood has a number of specific features concerning permeability (Redman et al. 2012). There are two features that are most important. The first is that wood has dramatic anisotropy ratios: permeability can be 1000 times greater in the longitudinal direction than in the transverse direction for softwoods, and this factor can be more than $10^{6}$ for hardwoods. The second is that heartwood is usually much less permeable than sapwood; in softwoods pit aspiration (full or partial closure); extractives (including resins) accumulations and tylosoids are mainly responsible for this difference. Heartwood formation also entails a shift of the mean pore size towards smaller radii (Schneider and Wagner 1974).

Even though wood is much more permeable longitudinally compared with the radial and tangential directions, in wood preservation there is usually a much greater reliance on radial and tangential liquid flow through wood rather than longitudinal movement. This is because most of the surface area presented to the penetrating fluid is lateral rather than transverse, and therefore it is lateral (radial and tangential) rather than longitudinal permeability which in most cases limits the response of a species to wood treatment (Banks 1972). Many studies have shown that radial permeability of wood is usually greater than tangential permeability (Yokota 1967; Choong and Fogg 1968; Comstock 1970; Isaacs et al. 1971; Petty 1975; Palin and Petty 1983; Milota et al. 1994; Cai et al. 1997), and for some southern pines the difference has been reported to be a factor of 150 for dry wood (Erickson 1938).

Wood permeability has been shown to vary with many factors, such as species, genetics, position in the tree, grain direction, drying conditions, moisture content, and method of storage before seasoning (Banks 1972). The range of this permeability variation is very large (Banks 1972). Permeability is closely linked to treatability, which in turn can be influenced by species, geographic origin, and growing conditions (Larnøy et al. 2008; Lande et al. 2010; Zimmer et al. 2014).

Anatomical features of wood directly influence the permeability of wood, and therefore any factors linked to wood anatomy can affect the wood permeability. Key anatomical features in softwood that influence permeability include annual ring width, latewood/earlywood proportions, the shape, size, and frequency of pits in tracheids; and whether the pits are unaspirated (open) or aspirated (closed). Other anatomical features that influence permeability include the size and frequency of radial and axial resin canals, parenchyma rays, and the amount and constitution of heartwood (Zimmer et al. 2014). Interstitial spaces created by certain drying conditions can also increase wood permeability (Bamber 1972; Booker 1990; Ahmed and Moren 2012).

Wood chemistry can also have a very important impact on wood permeability through the effect of wood extractives (including resins) that can block liquid flow (Ellwood and Ecklund 1961; Fogg 1968; Olsson et al. 2001; Baraúna et al. 2014). 
The formation of resin canals and resinous blemishes in pine stems and wood has been shown to be influenced by genetic constitution and by the growing conditions, including silvicultural procedures such as stocking rate and thinning (Cown et al. 2011). This suggests that the resin content may vary in the $\mathrm{PEE} \times \mathrm{PCH}$ hybrid pine due to genotype and stocking intensity.

With the exception of a previous study undertaken on tangential permeability (Leggate et al. 2017), the wood permeability of the $\mathrm{PEE} \times \mathrm{PCH}$ hybrid pine in Australia has not been studied. Given the importance of this resource to the Australian forest industry and the significant role that permeability plays in wood processing and product performance, a study was undertaken to investigate the variation in radial wood permeability of the PEE $\times \mathrm{PCH}$ hybrid pine resource in Australia in relation to genotype, tree stocking rate (stems per hectare), position in the tree on a horizontal axis (pith to bark), and resin content.

\section{EXPERIMENTAL}

\section{Materials and Methods}

Tree sampling

A set of 30 trees was selected from Experiment $622 \mathrm{NC}$, an $\mathrm{F}_{1}$ (first filial hybrid of $\mathrm{PEE} \times \mathrm{PCH}$ ) taxon (clones and $\mathrm{F}_{1}$ family) spacing trial planted during March 1997 within compartment 202 Donnybrook LA (26 58' 30" S; 152 59' 00” E), SF 611 Beerburrum, north of Brisbane, Queensland, Australia. The trees were 19 years old at the time of harvest in October 2016 and represented a broad range of stocking rates, from low stocking rates (i.e. wide spacing) at 200 stems per hectare (spha) and 333 spha, to medium stocking rates of 500 spha and 666 spha, to higher stocking rates of 1000 spha. The trees selected also represented three different $F_{1}$ genotypes: $F_{1}$ seedling (a routine plantation seedlot (a single cross family)), Clone 887 (selected for good growth and flat fine branches), and Clone 625 (selected for heavy branches as a contrast to clone 887). As per Table 1, two trees from each stocking rate and genotype combination were harvested in order to provide samples for wood property analysis.

Table 1. Tree Sampling Criteria (number of trees sampled for each genotype and stocking rate combination)

\begin{tabular}{|l|c|c|c|c|c|c|}
\hline \multirow{2}{*}{ Genotype } & \multicolumn{5}{|c|}{ Stocking Rates } & \multirow{2}{*}{$\begin{array}{c}\text { Total } \\
\text { (number of trees } \\
\text { sampled) }\end{array}$} \\
\cline { 2 - 6 } & $\begin{array}{c}200 \text { spha } \\
\text { (number } \\
\text { of trees } \\
\text { sampled) }\end{array}$ & $\begin{array}{c}333 \text { spha } \\
\text { (number } \\
\text { of trees } \\
\text { sampled) }\end{array}$ & $\begin{array}{c}500 \text { spha } \\
\text { (number } \\
\text { of trees } \\
\text { sampled) }\end{array}$ & $\begin{array}{c}666 \text { spha } \\
\text { (number of } \\
\text { trees } \\
\text { sampled) }\end{array}$ & $\begin{array}{c}1000 \text { sphan } \\
\text { (number of } \\
\text { trees } \\
\text { sampled) }\end{array}$ & \\
\hline F1 Seedling & 2 & 2 & 2 & 2 & 2 & 10 \\
\hline Clone 887 & 2 & 2 & 2 & 2 & 2 & 10 \\
\hline Clone 625 & 2 & 2 & 2 & 2 & 2 & 10 \\
\hline Total & $\mathbf{6}$ & $\mathbf{6}$ & $\mathbf{6}$ & $\mathbf{6}$ & $\mathbf{6}$ & $\mathbf{3 0}$ \\
\hline
\end{tabular}

The diameter at breast height over bark (DBHOB) was recorded for each selected tree. One transverse disc ( $35 \mathrm{~cm}$ thickness) was taken from each tree at $2.34 \mathrm{~m}$ height. 


\section{Laboratory assessments}

Samples for permeability and resin content determination were cut from three radial locations on each disc (close to the pith, mid-radius (between pith and bark), and close to the bark (Fig. 1)). The target dimensions of the permeability samples were $22 \mathrm{~mm}$ in diameter and $8 \mathrm{~mm}$ in length (flow direction). The target dimensions of the samples for resin content determination were $28 \mathrm{~mm}$ x $15 \mathrm{~mm}$ x $9 \mathrm{~mm}$. The permeability samples were cut from pith-to-bark diametral strips with growth rings aligned perpendicular to the transverse surface, so that gas and liquid permeability could be measured only in the radial grain direction (Fig. 1).

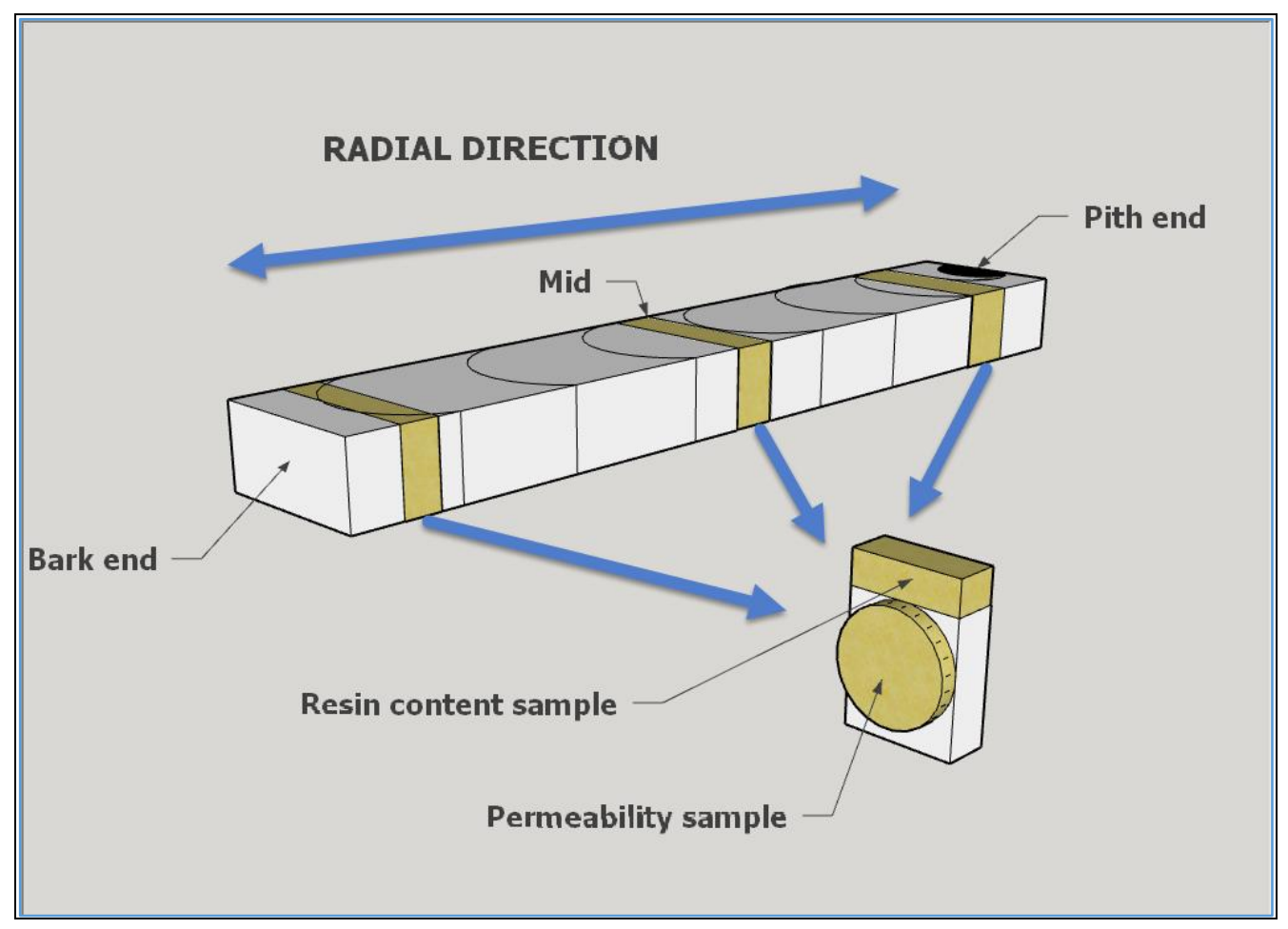

Fig. 1. Permeability and resin content samples cut from disc at three radial locations from pith to bark

The cambial age (ring number from the pith), chronological age (number of years since planting), and distance from the pith were recorded for each sample. Each permeability sample was coated with an epoxy resin on its lateral surface (periphery of the disc). This was done in order to direct gas and liquid movement only in the radial direction in order to measure radial permeability.

Prior to analysis, the permeability and resin content samples were conditioned to $8 \%$ moisture content (MC) in a constant environment chamber controlled at $23^{\circ} \mathrm{C}$ and $44 \%$ relative humidity. Gas (atmospheric air) and liquid (non-distilled water) radial permeability measurements were undertaken using a Porolux 1000 Porometer (IB-FT GmbH, Berlin, Germany). This is a laboratory device that can measure the pore size and permeability of materials. Gas permeability was performed on samples prior to liquid permeability. For gas permeability, samples were subjected to pressurized, atmospheric air until pressure reached the target pressure of 4200 millibars. For liquid permeability, samples were subjected to pressurized water (non-distilled) with a constant pressure of 4200 millibars for 5 min. Permeability calculations take into account the viscosity values for water (non-distilled) 
and for atmospheric air as influenced by temperature. The permeability test undertaken using the Porolux 1000 equipment is shown in Fig. 2. Permeability for each sample was recorded in millidarcy units $(\mathrm{mD})$.

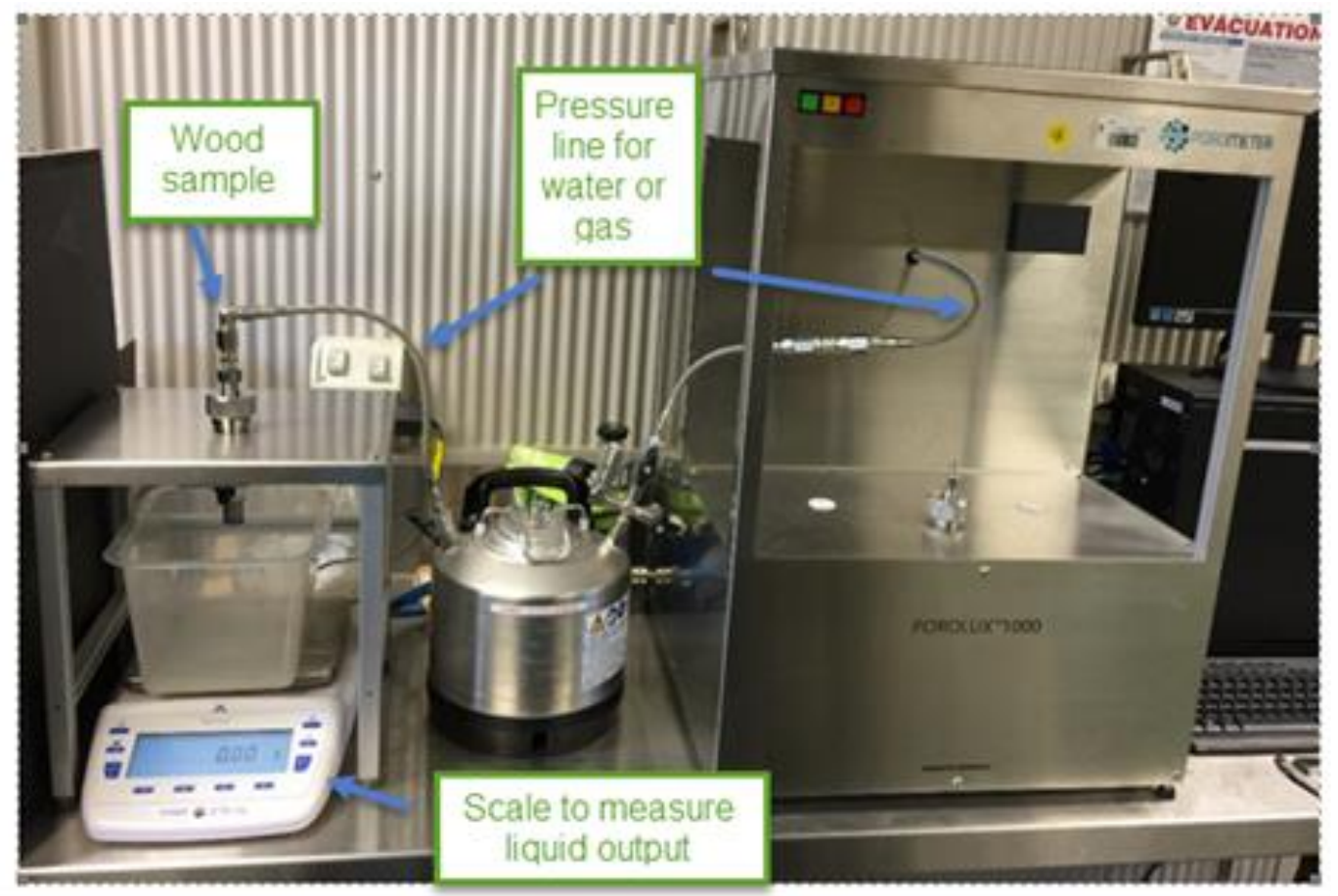

Fig. 2. Permeability test being undertaken using the Porolux 1000

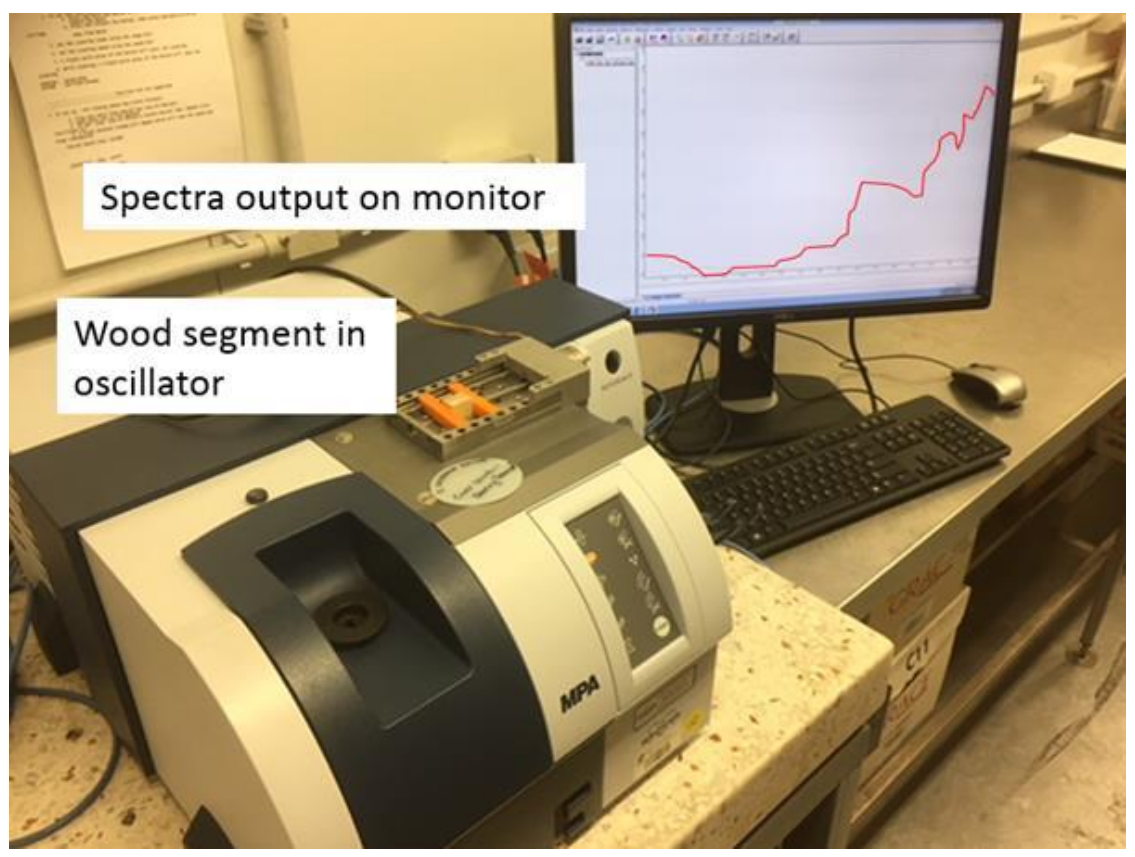

Fig. 3. Rapid resin content screening of wood samples using the Bruker MPA near infrared spectrometer 
Resin content (dichloromethane (DCM), ethanol and water extraction basis), was predicted for each sample using a Bruker MPA Fourier transform near infrared spectrometer (NIRS) (Bruker, Billerica, MA, USA) (Fig. 3). A previous study (Bailleres et al. 2017) had developed a calibration equation returning a coefficient of cross validation of 0.98 using the partial least square regression approach to enable total resin content to be predicted from NIRS solid sample spectrum.

\section{Data Analysis}

Statistical analysis was undertaken using GENSTAT (Release 19, VSNI, Hemel Hempstead, United Kingdom). The response variables of interest were permeability (gas and liquid) and resin content. The other variables were genotype, stocking rates, tree diameter, distance from the pith, cambial age, and chronological age. Resin content was transformed by taking its logarithm before statistical analysis. A number of permeability values were zero, and to calculate correlations the zero values were replaced by half the minimum observed value and logarithms were then taken. Then the correlation matrix was calculated for stocking rate, estimated distance from pith, mean chronological age, mean cambial age, tree DBH, logarithm of resin content, logarithm of gas permeability, and logarithm of liquid permeability.

For other analyses, generalized linear models were fitted to untransformed data with a quasi-Poisson response and a logarithmic link function, and Wald tests were used to determine the significance of effects.

Because the results from the pith samples were very different from the non-pith samples, separate analyses were also undertaken for pith and non-pith samples as well as all data. Fitting generalized linear mixed models for position to permeability with a component for tree-to-tree variation gave estimates for this component which were less than their estimated standard error, and this component was ignored in the analyses reported here.

\section{RESULTS AND DISCUSSION}

Permeability data for each genotype and stocking rate are presented in Table 2 and from Fig. 4 to Fig. 7. The F1 seedling and C887 clone recorded the highest and lowest mean radial permeabilities (gas and liquid), respectively. However, the differences in permeability between genotypes were not statistically significant. Likewise, there were no significant differences in radial permeability due to stocking rate. However, the highest stocking rate (1000 spha) recorded the lowest gas and liquid mean permeability.

A significant positive relationship was found between gas and liquid permeability $\left(\mathrm{R}^{2}=0.79, \mathrm{P}<.001\right)$. Other studies have also reported high correlations between gas and liquid permeability (Comstock and Côté 1968; Taghiyari 2012). Gas permeability was on average around 19 times higher than liquid permeability. Other studies have also shown that gas permeability in wood is higher than liquid permeability. For example, Siau (1984) reported that permeability to atmospheric air in wood was 55 times higher than that due to water at the same temperature. The main reasons for this are the higher viscosity of liquids (Rezende et al. 2018) and also that gases do not usually interact with cell wall materials in the wood but liquids may have chemical and physical interactions with them mainly via the wood hydroxyl groups (Taghiyari 2012). 
Table 2. Radial Permeability Data for Each $F_{1}$ Genotype and Stocking Rate

\begin{tabular}{|l|c|c|c|c|c|c|c|c|c|c|c|c|}
\hline \multirow{2}{*}{ Gean Gas and Liquid Radial Permeability for Each Genotype and Stocking Rate } \\
\cline { 2 - 14 } & 200 spha & \multicolumn{2}{|c|}{333 spha } & 500 spha & 666 spha & 1000 spha & \multicolumn{2}{|c|}{$\begin{array}{c}\text { Overall } \\
\text { Mean }\end{array}$} \\
\cline { 2 - 13 } & $\begin{array}{c}\text { Gas } \\
(\mathrm{mD})\end{array}$ & $\begin{array}{c}\text { Liquid } \\
(\mathrm{mD})\end{array}$ & $\begin{array}{c}\text { Gas } \\
(\mathrm{mD})\end{array}$ & $\begin{array}{c}\text { Liquid } \\
(\mathrm{mD})\end{array}$ & $\begin{array}{c}\text { Gas } \\
(\mathrm{mD})\end{array}$ & $\begin{array}{c}\text { Liquid } \\
(\mathrm{mD})\end{array}$ & $\begin{array}{c}\text { Gas } \\
(\mathrm{mD})\end{array}$ & $\begin{array}{c}\text { Liquid } \\
(\mathrm{mD})\end{array}$ & $\begin{array}{c}\text { Gas } \\
(\mathrm{mD})\end{array}$ & $\begin{array}{c}\text { Liquid } \\
(\mathrm{mD})\end{array}$ & $\begin{array}{c}\text { Gas } \\
(\mathrm{mD})\end{array}$ & $\begin{array}{c}\text { Liquid } \\
(\mathrm{mD})\end{array}$ \\
\hline $\begin{array}{l}\text { F1 } \\
\text { Seedling }\end{array}$ & 78.9 & 2.5 & 53.5 & 3.4 & 69.6 & 3.5 & 78.3 & 3.3 & 41.3 & 3.3 & 64.1 & 3.2 \\
\hline $\begin{array}{l}\text { Clone } \\
887\end{array}$ & 61.2 & 4.4 & 30.0 & 1.3 & 39.4 & 3.5 & 46.0 & 1.5 & 19.5 & 0.4 & 39.6 & 2.2 \\
\hline $\begin{array}{l}\text { Clone } \\
625\end{array}$ & 54.0 & 2.7 & 42.7 & 3.4 & 36.8 & 2.5 & 76.0 & 3.0 & 53.6 & 2.5 & 53.5 & 2.8 \\
\hline $\begin{array}{l}\text { Overall } \\
\text { Mean }\end{array}$ & 64.7 & 3.2 & 42.8 & 2.7 & 49.3 & 3.1 & 65.3 & 2.5 & 37.9 & 2.0 & 52.1 & 2.7 \\
\hline
\end{tabular}

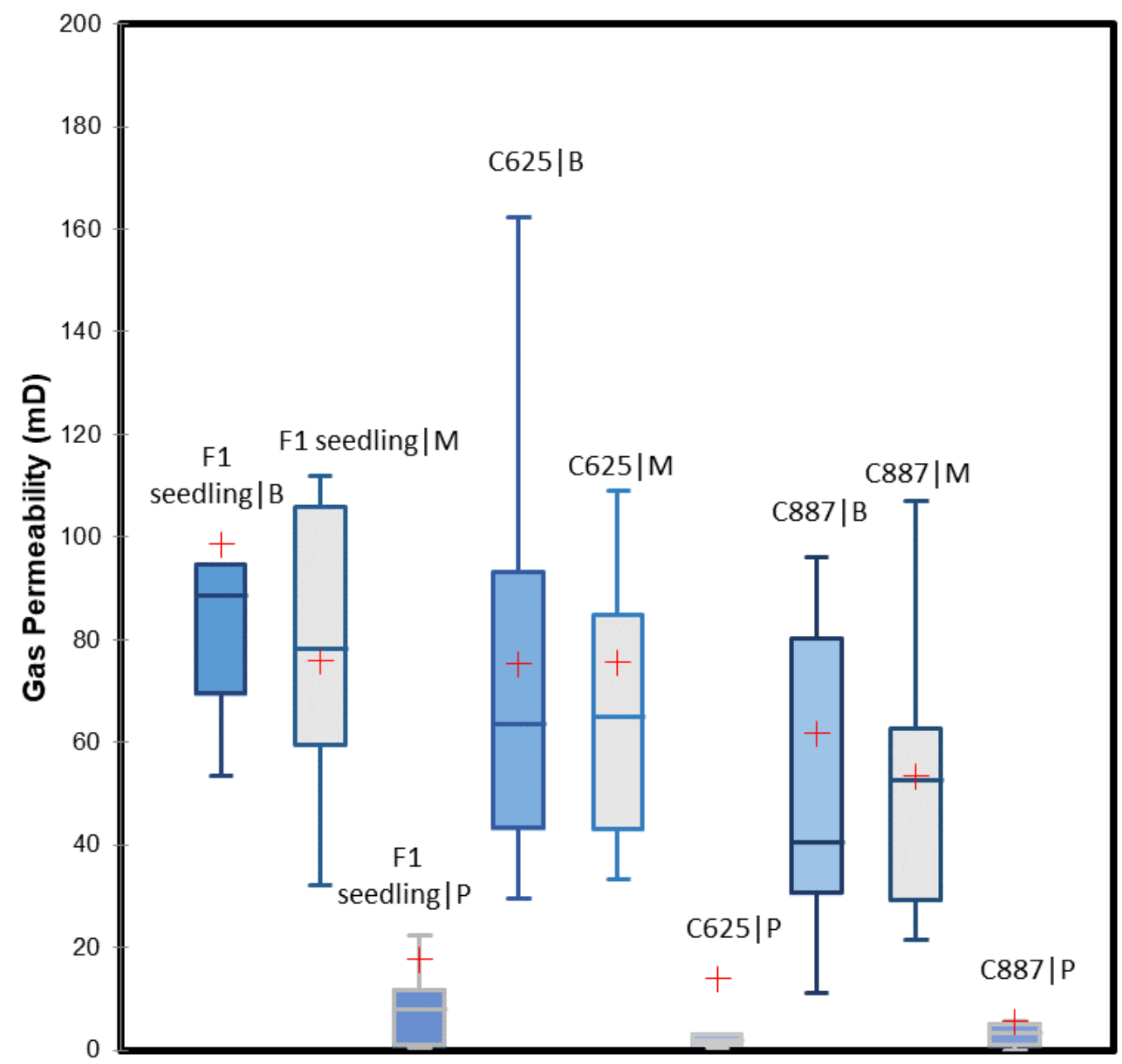

Fig. 4. Radial gas permeability of each $F_{1}$ genotype ( $F_{1}$ seedling, Clone 625 , Clone 887 ) at each radial position ( $\mathrm{B}$ (bark), $\mathrm{M}$ (middle), and $\mathrm{P}$ (pith)) (red cross is the mean; central horizontal bar is the median; the lower and upper limits of the box are the first and third quartiles, respectively) 


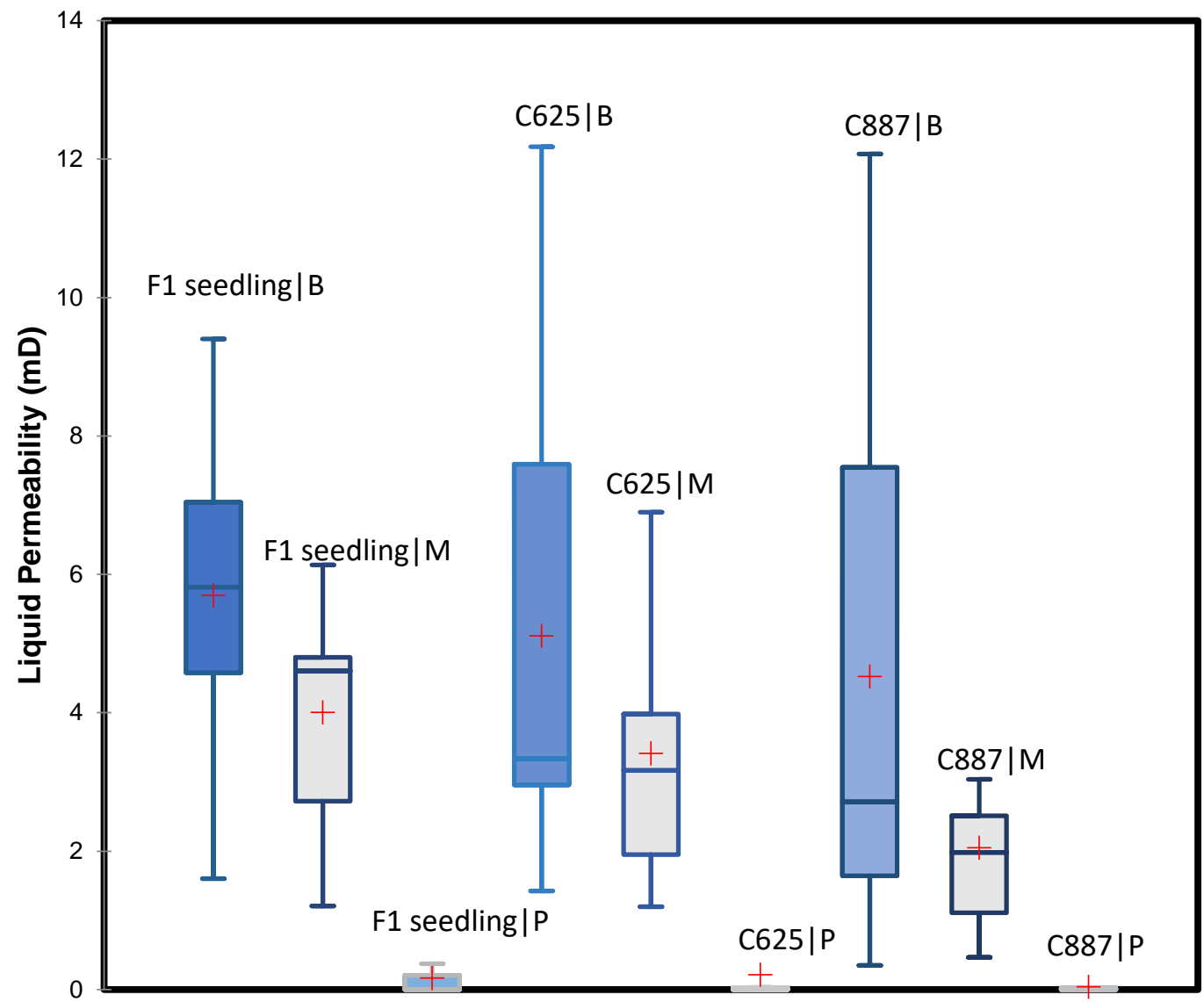

Fig. 5. Liquid permeability of each $F_{1}$ genotype ( $F_{1}$ seedling, Clone 625 , Clone 887$)$ at each radial position ( $\mathrm{B}$ (bark), $\mathrm{M}$ (middle), and $\mathrm{P}$ (pith)) (red cross is the mean; central horizontal bar is the median; the lower and upper limits of the box are the first and third quartiles, respectively)

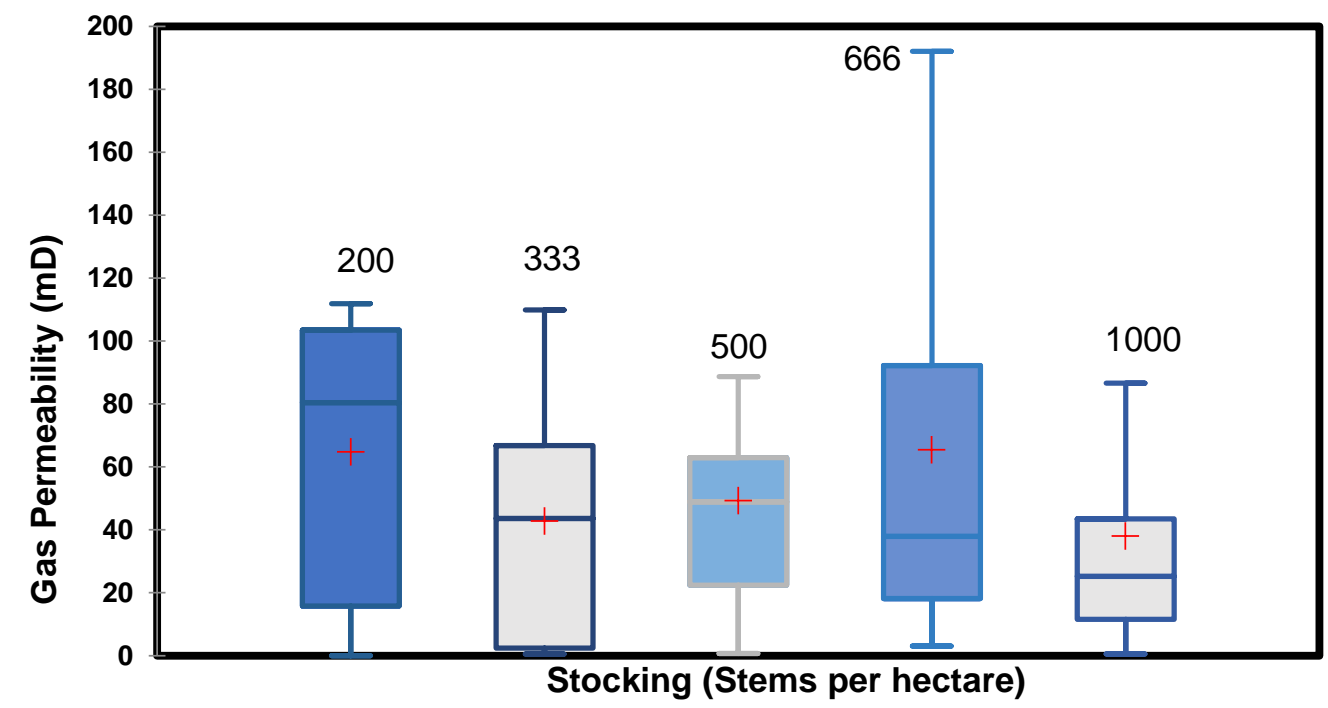

Fig. 6. Gas permeability for each $F_{1}$ stocking rate (red cross is the mean; central horizontal bar is the median; the lower and upper limits of the box are the first and third quartiles, respectively) 


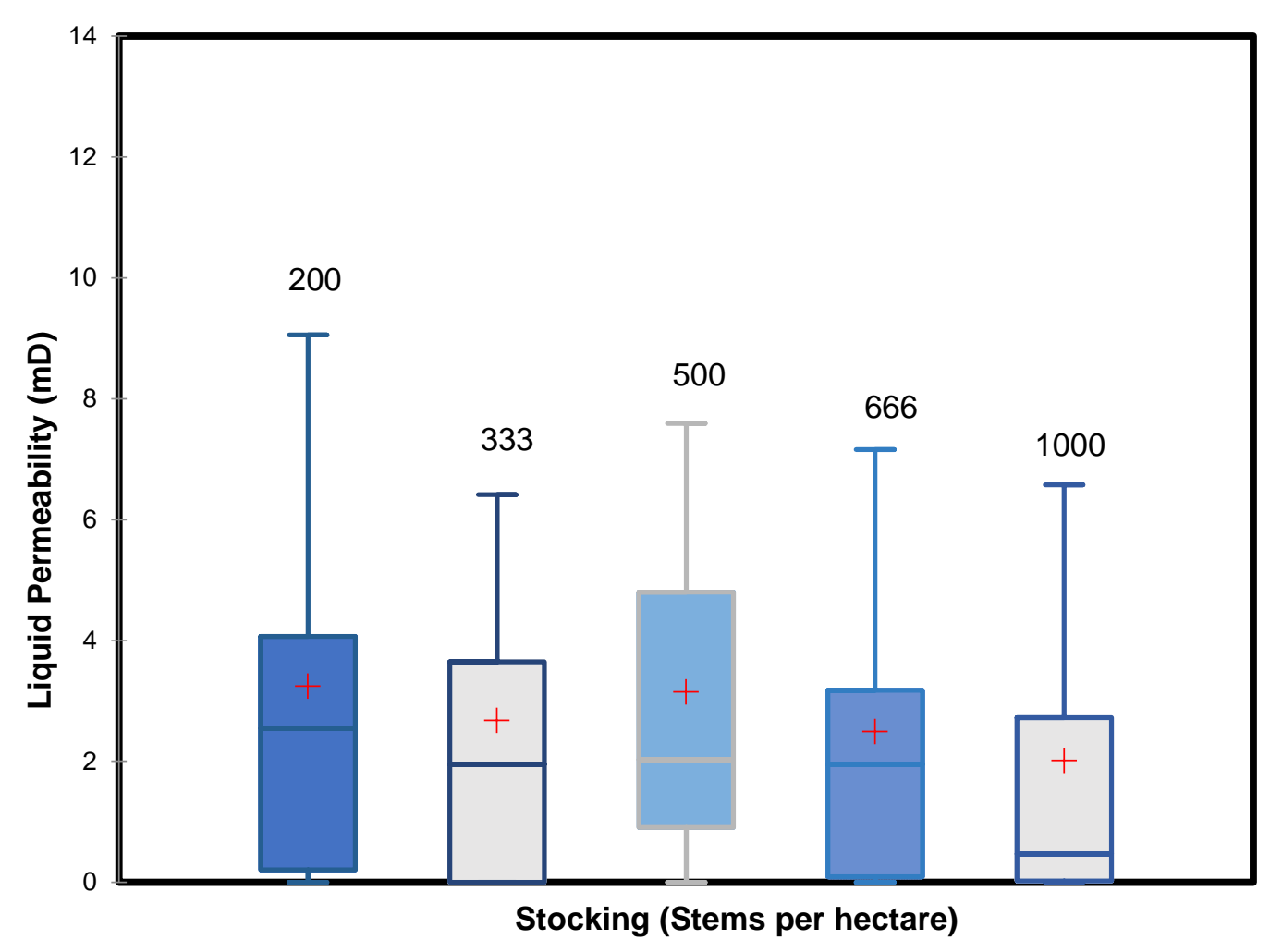

Fig. 7. Liquid permeability for each $\mathrm{F}_{1}$ stocking rate (red cross is the mean; central horizontal bar is the median; the lower and upper limits of the box are the first and third quartiles, respectively)

The differences in permeability within and between genotype and stocking rates would most likely be related to wood anatomical differences influenced by many factors, including genetics and growing conditions. Many other studies have demonstrated that treatability, which is closely linked to permeability, can vary within and between stands due to variation in wood anatomical characteristics influenced by factors such as geographic origin, climate, relative position of the tree in the stand, growth increments, and competition within a stand (Zimmer et al. 2014). Apart from wood anatomical variation, differences in wood chemistry (e.g. wood extractives or resin content) could also explain some of the variation as discussed below.

Differences in gas and liquid permeability according to radial position from pith to bark and for each genotype are shown in Fig. 4 and Fig. 5. Overall, mean gas and liquid permeability increased radially from the pith to the bark, and differences between radial positions were statistically significant in most cases (pith versus middle/bark: $\mathrm{p}<0.001$ for gas and liquid permeability; middle versus bark: $\mathrm{p}<0.01$ for liquid permeability; middle versus bark not significant for gas permeability).

This radial trend in permeability is consistent with the results from other studies on wood permeability (Hansmann et al. 2002). It is usually explained by the trend of reducing heartwood content radially from the pith to the bark (or increasing transformation of sapwood to heartwood from the bark inwards), although the extent of heartwood formation varies with age. The heartwood of most Pinus species is normally less permeable due to factors such as higher extractives (resins) content, greater pit aspiration, pit encrustation, reduced size and frequency of pits, and the presence of tylosoids. Specifically, for southern pines, Koch (1972) reports considerably higher extractives content in heartwood compared to sapwood. Leggate et al. (2017) also reported an increase in tangential liquid permeability 
from pith to bark in some southern pine taxa from Queensland and NSW plantations. Other studies on southern pines have shown that the permeability of sapwood can range from 15 to 12000 times the permeability of heartwood (Stamm 1931; Fogg 1968; Tesoro 1973). However, even in the absence of heartwood, permeability has been shown to decrease in the sapwood from the outer to the inner in all three anatomical directions (Hansmann et al. 2002). Juvenile wood has also been shown to have lower permeability than mature wood (Milota et al. 1994).

For all data combined, significant positive correlations $(\mathrm{p}<0.001)$ were found between wood radial permeability (gas and liquid) and distance from the pith $\left(\mathrm{R}^{2}=0.49\right.$ (gas); $\mathrm{R}^{2}=0.59$ (liquid)), chronological age $\left(\mathrm{R}^{2}=0.36\right.$ (gas); $\mathrm{R}^{2}=0.46$ (liquid)) and cambial age $\left(\mathrm{R}^{2}=0.36\right.$ (gas); $\mathrm{R}^{2}=0.48$ (liquid)) No significant relationships were found between wood permeability and tree DBHOB.

Overall, $1 \%$ and $20 \%$ of gas and liquid permeability samples respectively registered zero permeability. These zero permeability results were most likely due to anatomical or chemical features of the wood in these samples that restricted fluid flow. In most cases it was the samples taken closest to the pith that registered zero permeability and pith samples generally had higher resin contents. Further wood anatomical and chemistry studies could also help further explain why certain samples had no radial liquid flow. Other studies have also reported zero or extremely low transverse wood permeability (radial and tangential) results (Silva 2007; Baraúna 2010; Rezende et al. 2018). The differences in resin content (percentage of unextracted oven dry mass) between genotype and stocking rates are presented in Fig. 8 and Fig. 9. There were no significant differences in resin content due to genotype, however higher stocking rates had lower resin content $(\mathrm{p}<.05)$.

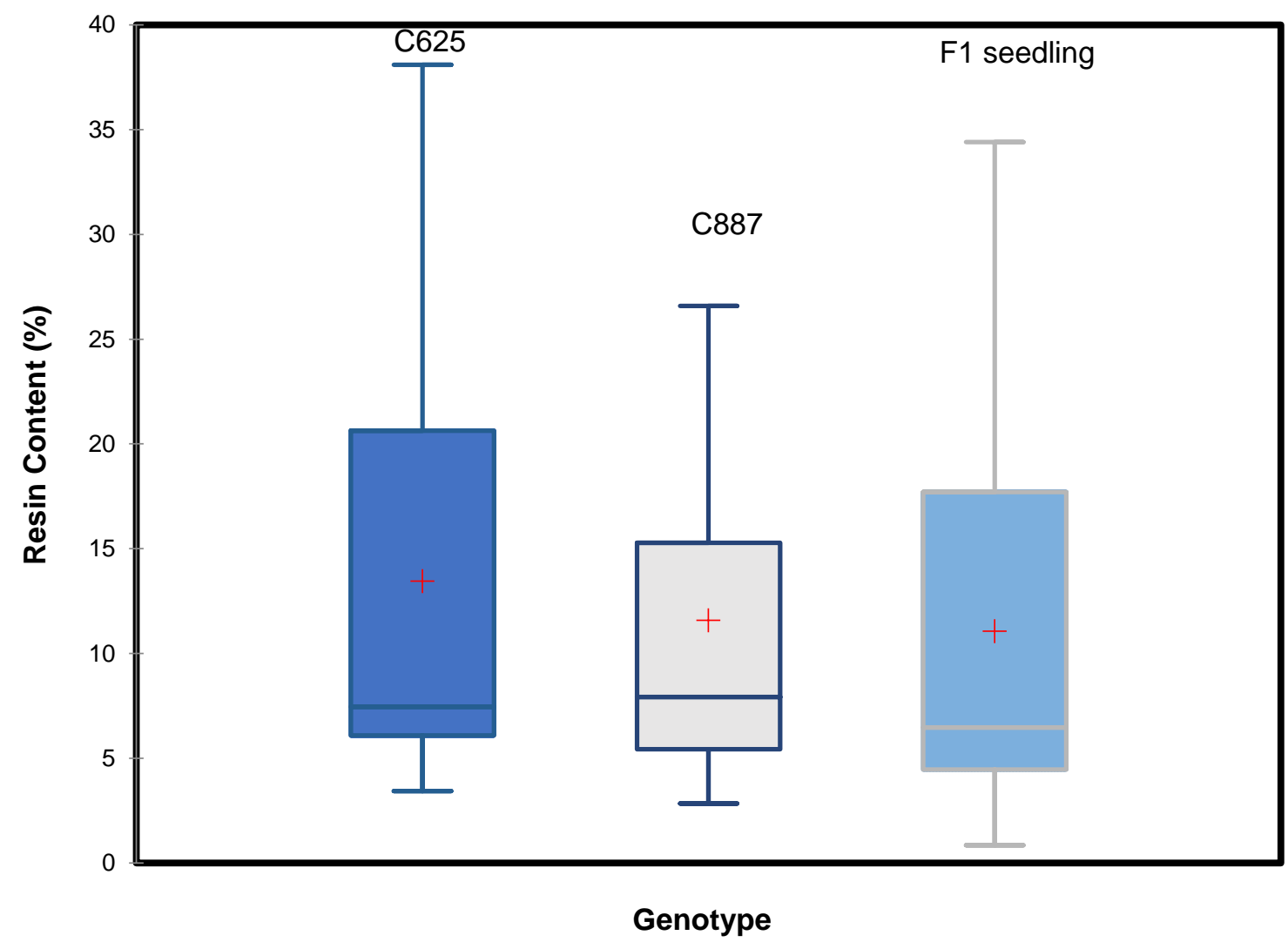

Fig. 8. Resin content of each $F_{1}$ genotype (red cross is the mean; central horizontal bar is the median; the lower and upper limits of the box are the first and third quartiles, respectively) 


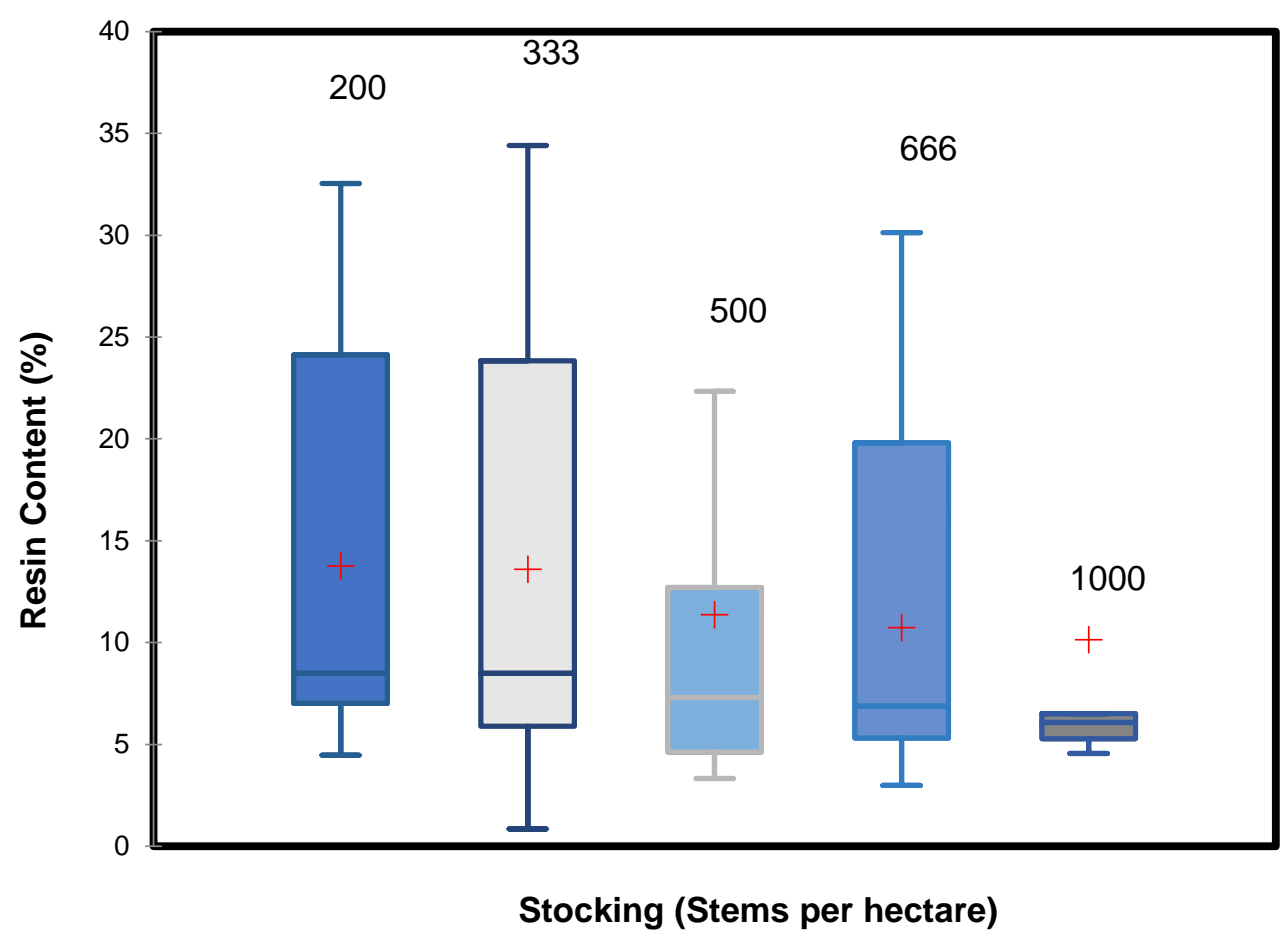

Fig. 9. Resin content for each $\mathrm{F}_{1}$ stocking rate (red cross is the mean; central horizontal bar is the median; the lower and upper limits of the box are the first and third quartiles, respectively)

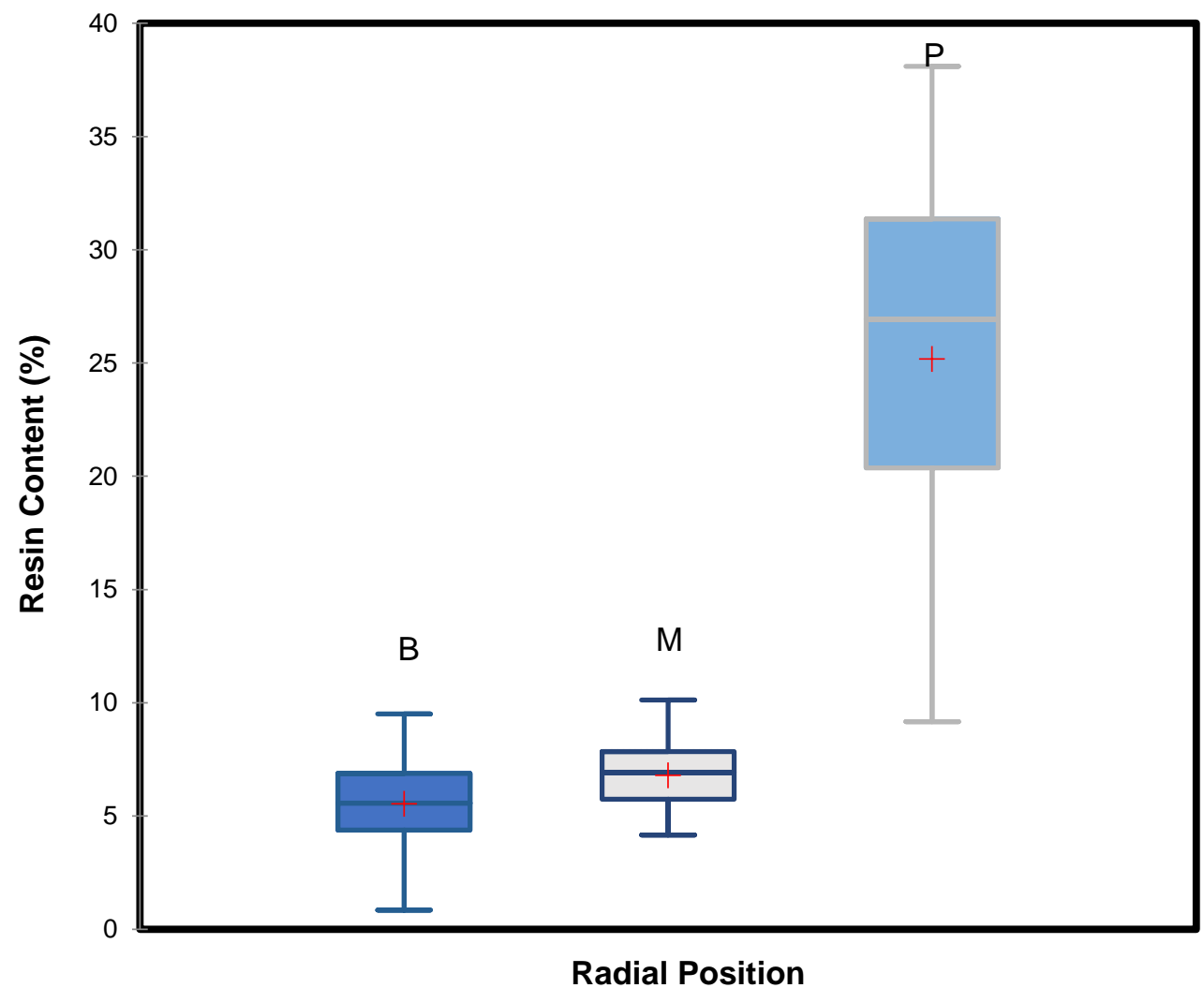

Fig. 10. Resin content of wood samples from each radial position (red cross is the mean; central horizontal bar is the median; the lower and upper limits of the box are the first and third quartiles, respectively) 
A highly significant negative relationship was found between permeability (both gas and liquid) and resin content for all data combined (gas permeability and resin content: $\mathrm{R}^{2}=0.56 ; \mathrm{p}<0.001$; liquid permeability and resin content: $\left.\mathrm{R}^{2}=0.65 ; \mathrm{p}<0.001\right)$. Therefore, wood with high resin content tended to have lower permeability.

The difference in resin content according to radial position from pith to bark is shown in Fig. 10. Overall, for all data combined, resin content decreased from pith to bark, with the differences between the pith and middle and pith and bark being much greater than the differences between the middle and bark positions. Differences in radial position for resin content were statistically significant ( $\mathrm{p}<0.001$ for pith versus middle/bark; $\mathrm{p}<.01$ for middle versus bark). The higher resin content in the center of the tree was most likely linked to the greater heartwood content in this position compared to the outer part of the tree. The higher resin content in the pith position also corresponded with the lower permeability found in this study.

For all data combined, significant negative relationships were found between resin content and distance from the pith $\left(\mathrm{R}^{2}=0.55 ; \mathrm{p}<.001\right)$, chronological age $\left(\mathrm{R}^{2}=0.52 ; \mathrm{p}<\right.$ $.001)$ and cambial age $\left(\mathrm{R}^{2}=0.53 ; \mathrm{p}<.001\right)$. No significant relationships were found between resin content and tree DBHOB, which suggested that resin accumulation was influenced by age rather than diameter of the $\mathrm{F}_{1}$ hybrids.

\section{CONCLUSIONS}

1. For all data combined, there was no significant effect of $F_{1}$ genotype or stocking rates on radial permeability (gas and liquid).

2. There were no significant differences in resin content due to $F_{1}$ genotype. However, higher stocking rates resulted in lower resin content.

3. Gas and liquid permeability were significantly positively correlated.

4. There was a highly significant increase in permeability from pith to bark for both gas and liquid measurements. Resin content showed an inverse trend with a highly significant decrease in resin content from pith to bark.

5. For all data combined, there was a highly significant negative relationship between permeability (gas and liquid) and resin content.

\section{ACKNOWLEDGMENTS}

The authors are grateful for the support of the Queensland Government, Department of Agriculture and Fisheries (DAF), the Forest and Wood Products Australia (FWPA), the University of the Sunshine Coast (USC), Forestry Commission NSW, Hancocks Queensland Plantations, Hyne and Son, and the Queensland University of Technology for their participation in the overarching project which this study formed part of - FWPA Project PNC361-1415, "Improving returns from southern pine plantations through innovative resource characterization".

Mr. John Oostenbrink, Mr. Bruce Hogg, and Mr. Tony Burridge (all DAF) are acknowledged for the field work involved in selecting and measuring trees and the acquisition of wood samples. 
Mr. Gary Hopewell, Mr. Jock Kennedy, Mr. Chris Fitzgerald, Mrs. Rica Minnett, Leslie Francis, John Huth, Cristina Latorre Beltran, and Hernan Retamales (all DAF) are acknowledged for their contribution with laboratory assessments of samples.

\section{REFERENCES CITED}

Ahmed, S. A., and Moren, T. (2012). "Moisture properties of heat-treated Scots pine and Norway spruce sapwood impregnated with wood preservatives," Wood Fiber Sci. 44(1), 85-93.

AS/NZS 1080.3:2000. (2000). “Timber - Methods of test density," Standards Australia, Sydney, Australia.

Bailleres, H., Hopewell, G., Hayes, A., and Francis, L. (2017). Interim Report-Variation in Extractives Predicted from Core Segments (Milestone report 6a), Forest and Wood Products Australia, Melbourne.

Bamber, R. K. (1972). "The formation and permeability of interstitial spaces in the sapwood of some Pinus species," J. Inst. Wood Sci. 6(2), 36-38.

Banks, W. B. (1972). "Factors affecting the introduction of preservatives into wood," Pestic. Sci. 3(2), 219-227. DOI: 10.1002/ps.2780030217

Baraúna, E. E. P. (2010). Permeability of Wood from Amapa (Brosimum parinarioides Ducke) and Faveira (Parkia gigantocarpa Ducke), Ph.D. Dissertation, Federal University of Lavras, Lavras, Brazil.

Baraúna, E., Lima, J., da Silva Vieira, R., da Silva, J., and Monteiro, T. (2014). "Effect of anatomical and chemical structure in the permeability of "Amapá" wood," CERNE 20(4), 529-534. DOI: 10.1590/01047760201420041501

Booker, R. E. (1977). "Problems in the measurement of longitudinal sapwood permeability and hydraulic conductivity," N. Z. J. For. Sci. 7(3), 297-306.

Booker, R. E. (1990). "Changes in transverse wood permeability during the drying of Dacrydium cupressinum and Pinus radiata," N. Z. J. For. Sci. (20), 231-244.

Cai, L., Avramadis, S., and Enayati, A. A. (1997). "Moisture sorption and movement in Parallam and timber strand," Holz Roh. Werkst. 55(6), 365-369. DOI: $10.1007 / \mathrm{s} 001070050248$

Choong, E. T., and Fogg, P. J. (1968). "Moisture movement in six wood species," For. Prod. J. 18(5), 66-70.

Comstock, G. L., and Côté, W. A. (1968). "Factors affecting permeability and pit aspiration in coniferous softwood," Wood Sci. Technol. 2(4), 279-291. DOI: 10.1007/BF00350274

Comstock, G. L. (1970). "Directional permeability of softwoods," Wood Fiber 1(4), 283289.

Cown, D. J., Donaldson, L. A., and Downes, G. M. (2011). “A review of resin features in radiata pine," N. Z. J. For. Sci. 41, 41-60.

Ellwood, E., and Ecklund, B. (1961). "Treatment to improve wood permeability as an approach to the drying problem," in: Proceedings Annual Meeting West Coast Kiln Club, Medford, Oregon.

Erickson, H. D. (1938). "The flow of liquid through radial resin canals," J. For. 36(4), 417-423.

Fogg, P. J. (1968). Longitudinal Air Permeability of Southern Pine Wood, Ph.D. Dissertation, Louisiana State University, Baton Rouge, Louisiana. 
Hansmann, C., Gindl, W., Wimmer, R., and Teischinger, A. (2002). "Permeability of wood - A review," Wood Res. 47(4), 1-16.

Isaacs, C. P., Choong, E. T., and Fogg, P. J. (1971). "Permeability variation within a cottonwood tree," Wood Sci. 3(4), 231-237.

Koch, P. (1972). Utilization of the Southern Pines - Volume 1. U.S. Department of Agriculture Forest Service Southern Forest Experiment Station, Asheville, NC.

Lande, S., Høibø, O., and Larnøy, E. (2010). "Variation in treatability of Scots pine (Pinus sylvestris) by the chemical modification agent furfuryl alcohol dissolved in water," Wood Sci. Technol. 44(1), 105-118. DOI: 10.1007/s00226-009-0272-3

Larnøy, E., Lande, S., and Vestol, G. I. (2008). "Variations on furfuryl alcohol and Wolmanit CX-8 treatability of pine sapwood within and between trees," in: $39^{\text {th }}$ Annual Meeting of the International Research Group on Wood Protection, Istanbul, Turkey.

Lee, D. (2015). Improving Returns from Southern Pine Plantations through Innovative Resource Characterization, Project Proposal, Forest and Wood Products Australia, Melbourne.

Leggate, W., Redman, A., and Bailleres, H. (2017). Wood Permeability of Southern Pine in Australia - Interim Report - Tangential Liquid Permeability (Milestone report 6B), Forest and Wood Products Australia, Melbourne.

Milota, M., Tschernitz, J., Verrill, S., and Mianowski, T. (1994). "Gas permeability of plantation loblolly pine," Wood Fiber Sci. 27(1), 34-40.

Nicholas, D. D., Schultz. T. P., Sites, L., and Buckner, D. (2005). "Effect of permeability and extractives on the decay rate of southern pine sapwood in above ground exposure," in: International Research Group on Wood Protection, Bangalore, India.

Olsson, T., Megnis, M. Varna, J., and Lindberg, H. (2001). "Study of the transverse liquid flow paths in pine and spruce using scanning electron microscopy," J. Wood Sci. 47(4), 282-288. DOI: 10.1007/BF00766714

Palin, M. A., and Petty, J. A. (1983). "Permeability to water of the wood cell wall and its variation with temperature," Wood Sci. Technol. 17(3), 187-193. DOI: 10.1007/BF00372316

Petty, J. A. (1975). "Relation between immersion time and absorption of petroleum distillate in a vacuum-pressure process," Holzforschung 29(4), 113-118. DOI: 10.1515/hfsg.1975.29.4.113

Redman, A., Bailleres, H., Turner, I., and Perré, P. (2012). "Mass transfer properties (permeability and mass diffusivity) of four Australian hardwood species," BioResources 7(3), 3410-3424. DOI: 10.15376/biores.7.3.3410-3424

Redman, A. (2017). Modelling of Vacuum Drying of Australian Hardwood Species, Ph.D. Dissertation, Queensland University of Technology, Brisbane, Queensland, Australia.

Rezende, R. N., Lima, J. T., de Ramos e Paula, L. E., Hein, P. R. and da Silva, J. R. (2018). "Wood permeability in Eucalyptus grandis and Eucalyptus dunnii," Floresta e Ambiente 25(1). DOI: 10.1590/2179-8087.022815

Sandberg, K., and Salin, J.-G. (2012). "Liquid water absorption in dried Norway spruce timber measured with CT scanning and viewed as a percolation process," Wood Sci. Technol. 46(1-3), 207-219. DOI: 10.1007/s00226-010-0371-1

Schneider, A., and Wagner, L. (1974). "Determination of pore size distribution in wood with a mercury porosimeter," (in German) Holz Roh. Werkst. 32(6), 216-224 DOI: 10.1007/BF02607257

Siau, J. F. (1984). Transport Processes in Wood, Springer-Verlag Berlin-Heidelberg, 
New York. DOI: 10.1007/978-3-642-69213-0

Silva, M. R. (2007). Determination of the Permeability of Brazilian Plantation Woods, Ph.D. Dissertation, University of São Paulo, São Paulo, Brazil.

Stamm, A. J. (1931). "Three methods of studying capillary structure as applied to wood," Physics 1(2), 116-128. DOI: 10.1063/1.1744989

Taghiyari, H. R. (2012). "Correlation between gas and liquid permeability in some nanosilver-impregnated and untreated hardwood," J. Trop. For. Sci. 24(2), 249-255.

Tesoro, F. O. (1973). Factors Affecting the Flow of Gas and Liquid Through Softwoods and Hardwoods, Ph.D. Dissertation, Louisiana State University, Baton Rouge, Louisiana.

Yokota, T. (1967). "Diffusion of non-swelling gas through wood," Mokuzai Gakkaishi $13,225-231$.

Zimmer, K. P., Høibø, O. A., and Vestøl, G. I., and Larnøy, E. (2014). "Variation in treatability of Scots pine sapwood: A survey of 25 different northern European locations," Wood Sci. Technol. 48(5), 1049-1068. DOI: 10.1007/s00226-014-0660-1

Article submitted: March 9, 2019; Peer review completed: April 8, 2019; Revised version received and accepted: April 9, 2019; Published: April 17, 2019.

DOI: $10.15376 /$ biores.14.2.4358-4372 